\title{
COMPLEMENT-MEDIATED KILLING OF UREAPLASMA UREALYTICUM BY ANTIBODY DIRECTED AGAINST COMPONENTS OF THE GROWTH MEDIUM
}

\begin{abstract}
J.-S. L. LIN
The Channing Laboratory, Department of Medicine, Harvard Medical School and Brigham and Women's Hospital, Boston, Massachusetts 02115, USA

SUMmary. Many strains of Ureaplasma urealyticum were inactivated, in the presence of complement, by a control antiserum prepared in guinea-pigs against the uninfected culture medium used to grow ureaplasmas. This mycoplasmacidal activity of the control serum, unlike that of the specific antisera prepared against the organisms themselves, was removed by treatment with dithiothreitol or by absorption with the horse-serum component of the medium, suggesting that the activity was due to an antibody of the IgM class acting on horse-serum proteins that had become associated with the surface of the ureaplasmas. The mycoplasmacidal activity in the specific ureaplasma antisera appeared to be due mainly to antibody of the IgG class. A similar complement-dependent mycoplasmacidal antibody to $U$. urealyticum, apparently active against serum components, was present in normal rabbit sera.
\end{abstract}

\section{INTRODUCTION}

We previously described a complement-dependent mycoplasmacidal test giving consistent and specific results for serotyping Ureaplasma urealyticum (Lin, Kendrick and Kass, 1972). There were no cross reactions with a control antiserum prepared against a concentrated preparation of uninfected growth medium. Subsequently, it was found that some batches of PPLO Broth (Difco), used as diluent in the test, were toxic for the ureaplasmas. However, when phosphate-buffered saline (PBS; Dulbecco and Vogt, 1954) was substituted as diluent, many strains of $U$. urealyticum were unexpectedly found to be inactivated by the control serum. The present paper reports an investigation of this phenomenon.

\section{MATERIALS AND METHODS}

Strains of U. urealyticum. Eleven strains, isolated in this laboratory (Lin et al., 1972), were maintained in a modified Hayflick medium, containing urea and consisting of Bacto PPLO Broth $70 \%(\mathrm{v} / \mathrm{v})$, horse serum $20 \%(\mathrm{v} / \mathrm{v})$, fresh yeast extract (Microbiological Associates) $10 \%$ $(\mathrm{v} / \mathrm{v})$, urea $0.5 \%(\mathrm{w} / \mathrm{v})$, phenol red $0.001 \%(\mathrm{w} / \mathrm{v})$ and benzyl penicillin $500 \mathrm{units} / \mathrm{ml}$.

Antisera against each of the 11 strains of Ureaplasma were obtained by immunising guineapigs with organisms grown in Hayflick medium, and control sera were prepared by a similar immunisation programme with uninfected medium (Lin and Kass, 1970). For each antigen, five guinea-pigs were immunised and a pool of sera was prepared.

Mycoplasmacidal tests. The strains were grown in Shepard's U17 medium without cystein (Shepard and Lunceford, 1978), but containing horse serum $5 \%(\mathrm{v} / \mathrm{v})$ or, for some experiments, guinea-pig serum $5 \%(\mathrm{v} / \mathrm{v})$, this medium being more suitable for preparation of test antigens than the modified Hayflick medium (Lin and Kass, 1980). The cultures, harvested at early logarithmic phase, were used directly as antigens in the mycoplasmacidal tests, which were done by the microtitration technique previously described (Lin, Kendrick and Kass, 1972). This method entails an initial incubation $\left(1 \mathrm{~h}\right.$ at $\left.37^{\circ} \mathrm{C}\right)$ of twofold serum dilutions with 10-100 $50 \%$ colour-change units of the ureaplasma test strain (antigen), in the presence of $c .10$ haemolytic 
units of guinea-pig complement (Lenette, 1964), followed by addition of growth medium with indicator and reincubation for 5 days. The mycoplasmacidal titre was the highest dilution of serum that inactivated the ureaplasma, as indicated by absence of any $p \mathrm{H}$ change indicating growth. PBS was used as diluent throughout and all sera were inactivated at $56^{\circ} \mathrm{C}$ for $30 \mathrm{~min}$ before testing.

For absorption of antibody against components of the growth medium, sera were incubated with an equal volume of the Hayflick growth medium, or equivalent amount of medium components, at $37^{\circ} \mathrm{C}$ for $1 \mathrm{~h}$ and then at $4^{\circ} \mathrm{C}$ overnight, and the mixtures were then centrifuged at $27000 \mathrm{~g}$ for $30 \mathrm{~min}$ to remove any precipitates.

To inactivate IgM (Pirofsky and Rosner, 1974; Olson et al., 1976), sera were treated with $40 \mathrm{~mm}$ dithiothreitol (DTT; Calbiochem) at room temperature for $1 \mathrm{~h}$ and then dialysed against PBS overnight at $4^{\circ} \mathrm{C}$. Sera treated only with PBS were included as controls.

\section{RESULTS}

The mycoplasmacidal activity of the control antiserum, prepared against the uninfected Hayflick growth medium, varied among the 11 ureaplasma strains. Three strains, U9, U26 and U30, were not significantly affected by the serum (mycoplasmacidal titre $<8$ ); four strains, K11, U23, U38 and T960, were moderately affected (titre 8-32); the other four strains, U19, K2, U24 and K393, were markedly affected (titre 128-512). Mycoplasmacidal activity was not demonstrable when tests were done with pre-immune guinea-pig serum, nor with the control serum in the absence of complement, nor with complement alone.

In an attempt to identify the components in the growth medium giving rise to the immune mycoplasmacidal activity of the control antiserum, the antiserum was absorbed either with whole growth medium or with an equivalent amount of each of its major constituents. When the various absorbed sera were tested against strains U19, U24 and K393, only the sera absorbed with whole medium or with horse serum showed loss of mycoplasmacidal activity (table I). That an anti-horse-serum antibody was the mycoplasmacidal factor in the control antiserum appeared to be confirmed by tests in which the control antiserum was reacted against ureaplasmas grown in medium containing guinea-pig serum instead of horse serum; in these tests, mycoplasmacidal activity was absent even in the presence of 20 or 40 haemolytic units of complement.

The specific antisera prepared against the 11 ureaplasma strains were also examined for loss of mycoplasmacidal activity after absorption with growth medium. Table II shows representative results obtained when the ureaplasma antisera were tested against two strains, U24 and K393, grown in media containing either horse serum or guinea-pig serum. Some of the absorbed sera showed loss of mycoplasmacidal activity for test strains grown in the presence of horse serum, but there was no loss of activity against the same organisms grown in the presence of guinea-pig serum. Moreover, the mycoplasmacidal titres of the absorbed antisera were essentially the same when tested against organisms grown in the presence of horse serum or guinea-pig serum.

The mycoplasmacidal activity of the control serum prepared against Hayflick medium was eliminated by treatment with DTT, indicating that an antibody of the IgM class was probably

TABLE I

Effect of absorption with culture-medium components on the mycoplasmacidal activity of control, anti-growth-medium antiserum

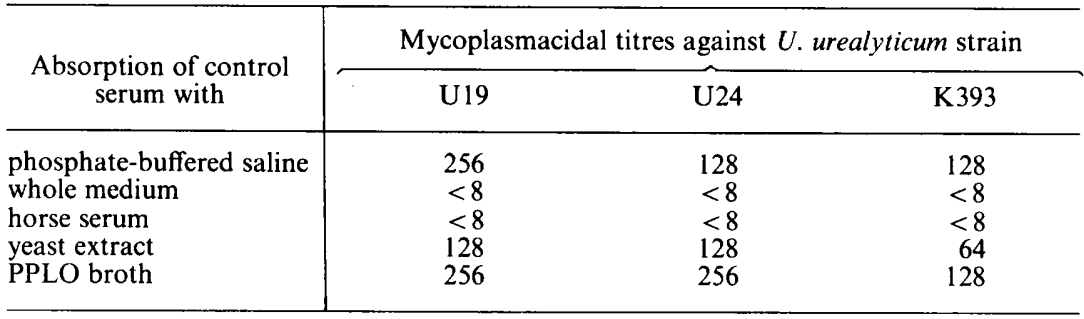




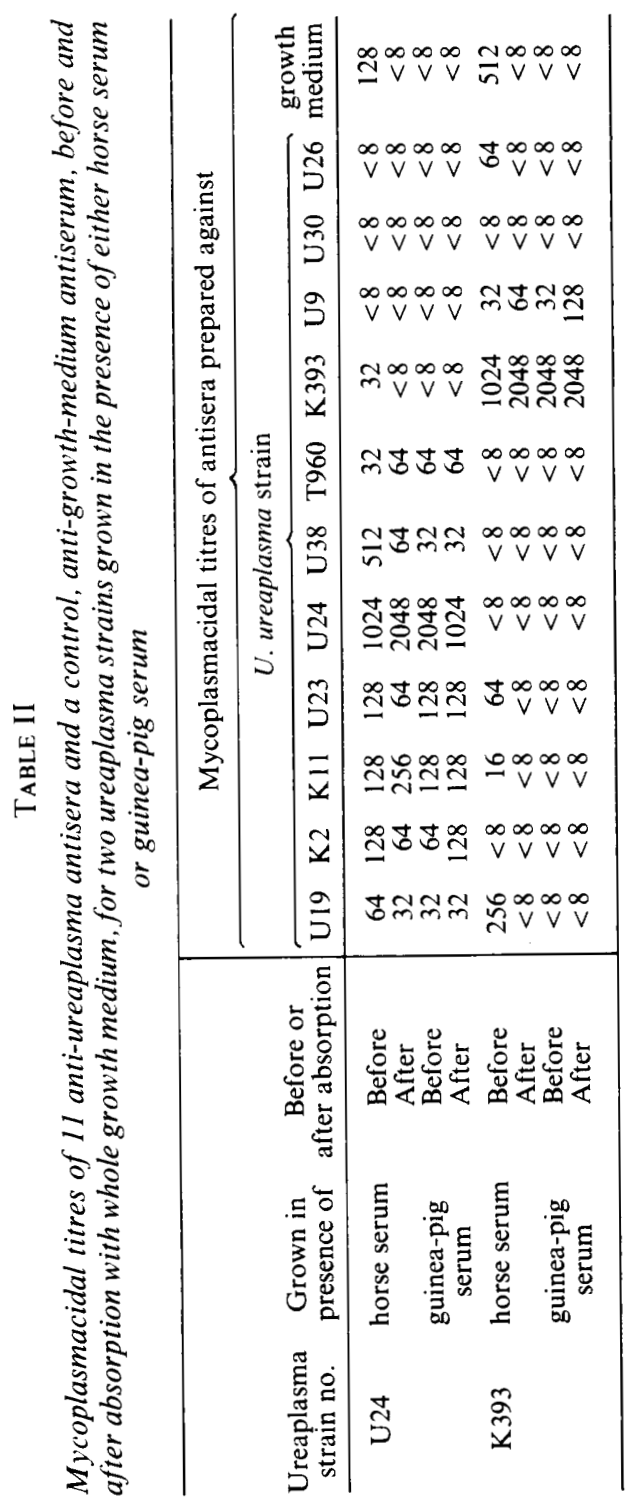


involved. On the other hand, the activity of the antisera prepared against the various ureaplasmas themselves was unaffected by DTT treatment, indicating that antibodies of the IgG class were mainly involved.

All normal rabbit sera (New Zealand white) that we have tested have also shown complement-dependent mycoplasmacidal activity, although more than 20 units of complement were required for consistent demonstration of this effect. This activity was DTT sensitive and absorption with horse serum removed most of the mycoplasmacidal activity for strains K2, U19 and K393, although not for U24. Unlike the control antiserum above, normal rabbit sera were mycoplasmacidal whether the antigen strains were grown in the presence of horse serum or of guinea-pig serum.

\section{Discussion}

Our results show that antibody directed against serum constituents of culture medium can kill ureaplasmas in the presence of complement, suggesting that these components become intimately associated with the ureaplasma surface. Treatment with DTT, which acts by reducing disulphide bonds, indicates that the antibody is IgM. It has been shown that one molecule of IgM combined with antigen on the cell surface is sufficient to activate complement through the classical pathway. On the other hand, two molecules of IgG side by side are required to produce this same effect (Frank, 1979). Sethi and Brandis (1972) have reported very similar complement-mediated effects on Mycoplasma gallisepticum and $M$. pneumoniae produced by antibody to horse serum present in growth media, likening this phenomenon to the "passive immune" effects noted with mammalian cells. It is of interest that "passive immune" inactivation of $U$. urealyticum by antibody to serum components of the medium appeared to be limited to IgM antibody. IgG antibody to the contaminating protein might affect other serological reactions more profoundly when non-viable antigens are used.

The sensitivity to the "passive immune" inactivation of $U$. urealyticum varied widely among the 11 strains that we have tested, but is not clear whether this variation reflects quantitative or qualitative differences in the nature of the serum-cell associations. The precise nature of this apparent association between medium components and $U$. urealyticum is not clear. Contamination of washed mycoplasmal cells with serum proteins from culture medium is a frequent problem in the preparation of specific mycoplasma antisera (Kenny, 1979). Although co-precipitation of specific serum proteins with mycoplasmal cells during preparative centrifugation can contribute to this problem (Yaguzhinskaya, 1976), selective associations of cells with some proteins might occur during cultivation (Wise, Cassell and Acton, 1978). Thus, $M$. hyorhinis grown in murine T-lymphoblastoid cell cultures selectively accumulated a lymphoid cell-surface alloantigen. At the same time $M$. bovis has been shown to "absorb" a wide range of medium serum proteins at $p H 6 \cdot 8-7 \cdot 2$ in vitro (Thorns and Boughton, 1980), while in the case of M. gallisepticum absorption occurred mainly at low $p \mathrm{H}$ (Bradbury and Jordan, 1972). Such contamination with culture-medium proteins can interfere with serological reactions, as reported for some mycoplasmas (Bradbury and Jordan, 1972), and alter the antigenic character or serological specificity of cell antigens (Smith, Dunlop and Strout, 1966; Sethi and Brandis, 1972; Masover, Mischak and Hayflick, 1975; Thorns and Boughton, 1980). However, the immune mycoplasmacidal reactions associated with components of the medium, described above, can be differentiated by the use of appropriate controls and by the class of antibody involved. Whether the associations of host components with the cell surface affect the pathogenicity or immunogenicity of mycoplasmas in vivo remains to be determined.

As previously reported, low dilutions of fresh guinea-pig (Hartley strain) serum inactivate many strains of $U$. urealyticum (Lin and Kass, 1970). This effect, however, is not due to antibody, because it is heat labile $\left(56^{\circ} \mathrm{C}\right.$ for $\left.30 \mathrm{~min}\right)$ and not restored by addition of fresh complement. On the other hand, the mycoplasmacidal effect of normal rabbit serum, in the presence of complement, also appears to be due to an IgM antibody that may be immunologically related to the anti-horse-serum antibody produced by immunising guinea-pigs with growth medium, because both are removed by absorption with horse serum. The precise nature of this effect remains uncertain, however, because it is not confined to ureaplasmas grown in the presence of horse serum. 
In contrast to the present findings, we previously reported that the 11 strains of Ureaplasma were not significantly affected by the control anti-medium serum even when antigens were grown with horse serum (Lin et al., 1972). Those tests had also been performed with $c .10$ units of complement, but with PPLO broth as a diluent. We have since noted, however, that when complement was increased to 20 or 40 units, many strains tested in PPLO broth diluent were inactivated by the control serum. It therefore appears that the amount of available complement is critical for demonstrating "passive immune" inactivation of ureaplasmas by antibody to serum components of the medium. For our serological comparisons of ureaplasmas, the potentially confounding effects on serological specificity of contaminating proteins from culture media have been avoided by absorbing all ureaplasma antisera with the growth medium and by preparation of all test antigens in medium with guinea-pig serum (table II). The specific cross-reacting patterns among 11 strains of $U$. urealyticum grown with guinea-pig serum remained essentially the same as those previously reported, whether tested with absorbed or unabsorbed sera (Lin and Kass, 1980). More generally, our results indicate that although the antigenic serum components of the medium may become physically associated with the ureaplasma surface, they are not irreversibly incorporated chemically into the membrane and the association does not interfere with specific reactions in vitro between ureaplasma membrane antigens and antibodies.

This work was supported by grant no. 2PO1 HD 11924 from the National Institute of Child Health and Human Development. I thank Dr E. H. Kass for reviewing the manuscript and Mrs C. W. Balchunass for assistance.

\section{REFERENCES}

Bradbury, J. M. and JoRdan, F. T. W. 1972. Studies on the adsorption of certain medium proteins to Mycoplasma gallisepticum and their influence on agglutination and haemagglutination reactions. J. Hyg., Camb. 70, 267.

DulBeCCO, R. AND VOGT, M. 1954. Plaque formation and isolation of pure lines with poliomyelitis virus. J. exp. Med., 99, 167.

Frank, M. M. 1979. The complement system in host defense and inflammation. Rev. infect. Dis., $1,483$.

Kenny, G. E. 1979. Antigenic determinants. In The mycoplasmas, vol I, edited by M. F. Barile and S. Razin, Academic Press, New York, p. 351.

LENNETTE, E. H. 1964. General principles underlying laboratory diagnosis of viral and rickettsial infections. Complement-fixation test. In Diagnostic procedures for viral and rickettsial diseases, 3rd ed., edited by E. H. Lennette and N. J. Schmidt, American Public Health Association, New York, p. 51.

LIN, J.-S. AND KaSS, E. H. 1970. Immune inactivation of T-strain mycoplasmas. J. infect. Dis. $122,93$.

LIN, J.-S. L. AND KASS, E. H. 1980. Fourteen serotypes of Ureaplasma urealyticum (T-mycoplasmas) demonstrated by the complement-dependent mycoplasmacidal test. Infection. 8, 152.

Lin, J.-S. L., Kendrick, M. I. And Kass, E. H. 1972. Serologic typing of human genital T-mycoplasmas by a complement-dependent mycoplasmacidal test. J. infect. Dis. 126, 658.

Masover, G. K., Mischak, R. P. And Hayflick, L. 1975. Some effects of growth medium composition on the antigenicity of a T-strain mycoplasma. Infect. Immun. 11, 530.

Olson, P. R., Weiblen, B. J., O’Leary, J. J., Moscowitz, A. J. And McCullough, J. 1976. A simple technique for inactivation of IgM antibodies using Dithiothreitol. Vox. Sang. 30, 149.

Pirofsky, B. AND RosNer, E. R. 1974. DTT test: a new method to differentiate IgM and IgG erythrocyte antibodies. Vox Sang. 27, 480.

Sethi, K. K. AND Brandis, H. 1972. Killing of mycoplasmas by the antibodies to foreign antigens acquired by the organisms from the growth medium. Med. Microbiol. Immun., $157,113$.

SHEPARD, M. C. AND LunCEFORD, C. D. 1978. Serological typing of Ureaplasma urealyticum 
isolates from urethritis patients by an agar growth inhibition method. J.clin. Microbiol. 8, 566.

Smith, S. C., Dunlop, W. R. AND Strout, R. G. 1966. Effect of culture medium on antigenic structure of mycoplasma. Avian Dis. 10, 173.

Thorns, C. J. AND Boughton, E. 1980. Studies on the effect of growth medium composition on the antigenicity of Mycoplasma bovis. J. Hyg., Camb., 84, 29.

Wise, K. S., Cassell, G. H. and Acton, R. T. 1978. Selective association of murine T lymphoblastoid cell surface alloantigens with Mycoplasma hyorhinis. Proc. natn. Acad. Sci. USA, 75, 4479.

YAGUZHINSKAYA, O.E. 1976. Detection of serum proteins in the electrophoretic patterns of total proteins of mycoplasma cells. J. Hyg., Camb., 77, 189. 